\title{
STRUKTUR KOMUNITAS EKOSISTEM MANGROVE DAN KEPITING BAKAU DI DESA LAMANGGO DAN DESA TOPE, KECAMATAN BIARO, KABUPATEN KEPULAUAN SIAU, TAGULANDANG, BIARO
}

\author{
(Mangrove Ecosystem Community Structure and Mangrove Crab in Lamanggo and \\ Tope Villages, Biaro Sub-District, Siau, Tagulandang and Biaro Islands District)
}

\section{Reinol Jacobs ${ }^{1 *}$, Janny D. Kusen¹, Calvyn F. A. Sondak1, Farnis B. Boneka1, Veibe Warouw', Winda M. Mingkid ${ }^{2}$}

1. Program Studi IImu Kelautan, Fakultas Perikanan dan IImu Kelautan, Universitas Sam Ratulangi, Manado

2. Program Studi Budidaya Perairan, Fakultas Perikanan dan IImu Kelautan, Universitas Sam Ratulangi, Manado.

*e-mail : reinoljacobs@yahoo.co.id

The goals of this study was to find out mangrove community structure in Lamanggo and Tope Village, abundance of mangrove crab, the relationship between mangrove crab density and mangrove density. This study was carried out using the line transect quadrant method within five observations sampling point location. The mangrove conditions was analyzed by density, frequency, dominance, diversity indices and importance value index as well as linear relationship of mangrove crab abundance analysis related to the density of mangroves with the formula $Y=a+b X$. The results found that Rhizophora apiculata has the highest density and the highest frequency value, whereas Sonneratiaalba has the highest dominance. Based on correlation test between mangrove trees density $(X)$ against crabs density $(\mathrm{Y})$ shown by $r=0.814$ by $\mathrm{F}_{\text {calc of }} 1.94<\mathrm{F}_{\text {tabel }} 10.12$, it can be concluded that, there was no significant relationship between mangrove crab density and mangroves density. More over, to find out the contribution rate of mangrove crab density to mangrove density by used determination coefficient of $\mathrm{R}^{2}=0.66$ then found the variable of mangrove tree density does not contribute to the crab density, because every addition of a variable $\mathrm{X}$,caused $\mathrm{Y}$ variable reduced by $67.54937-0110 \mathrm{X}$.

Keywords: mangrove, mangrove crabs, diversity, structure community

Tujuan dari penelitian yaitu untuk mengetahui struktur komunitas mangrove di Desa Lamanggo dan Desa Tope, untuk mengetahui kelimpahan kepiting bakau di hutan mangrove, dan untuk mengetahui hubungan antara kerapatan mangrove dengan kepadatan kepiting.Penelitian dilakukan dengan menggunakan metode line transek kuadran dengan menentukan lima lokasi titik pengamatan pengambilan sampel, dan untuk mengetahui kondisi mangrove maka dilakukan perhitungan kerapatan jenis, frekuensi jenis, penutupan jenis, dominasi, indeks nilai penting dan keanekaragaman serta analisis kelimpahan kepiting bakau yang berhubungan dengan kerapatan mangrove dengan rumus $Y=a+b X$. Dari hasil penelitian yang dilakukan, diketahui bahwa jenis mangrove yang memiliki nilai kerapatan tertinggi yaitu Rhizophora apiculata, dan untuk nilai frekuensi tertinggi juga yaitu jenis Rhizophora apiculata, sedangkan untuk nilai dominasi tertinggi dimiliki oleh jenis Sonneratia alba.Berdasarkan uji korelasi antara kerapatan pohon mangrove (X) terhadap kepadatan kepiting (Y) sebagaimana terlihat diperoleh $r$ sebesar $=0,814$ dengan F $F_{\text {hitung sebesar } 1.94<}$ Ftabel 10.12. Hal ini berarti tidak terdapat hubungan yang signifikan antara kerapatan mangrove dengan kepadatan kepiting bakau. Selanjutnya untuk melihat besarnya kontribusi kerapatan mangrove terhadap kepadatan kepiting dicari melalui koefisien determinasi $\mathrm{R}^{\mathbf{2}}=0.66$ yang berarti variabel kerapatan pohon mangrove tidak memberikan kontribusi terhadap kepadatan kepiting. Karena jika setiap penambahan variabel X, maka variabel Y akan berkurang sebesar $67.54937-0.110 \mathrm{X}$.

Kata kunci: mangrove, kepiting bakau, keanekaragaman, struktur komunitas 


\section{PENDAHULUAN}

Mangrove merupakan ekosistem yang berada pada wilayah intertidal, dimana pada wilayah tersebut terjadi interaksi yang kuat antara perairan laut, payau, sungai dan terestrial. Interaksi ini menjadikan ekosistem mangrove mempunyai keanekaragam yang tinggi baik berupa flora maupun fauna (Martuti, 2013).

Menurut Kusen et al. (2016) dari segi ekologi perairan, ekosistem mangrove terkait dengan peranannya baik sebagai habitat flora dan fauna air, sebagai tempat mencari makan (feeding ground), tempat memijah (spawning ground), tempat pengasuhan (nursery ground) dan tempat berlindung, maupun peranannya sebagai sumber plasma nutfah dan sumber energi bagi kehidupan di perairan estuari dan laut.

Menurut La Sara (2010) kepiting bakau merupakan salah satu dari kelompok krustasea yang habitat utamanya berada di ekosistem mangrove karena seluruh siklus hidupnya berhubungan erat dengan ekosistem mangrove. Di Indonesia, kepiting bakau tersebar luas dari barat (Sumatera) ke timur (Papua) yang tersebar di banyak wilayah pesisir yang memiliki hutan mangrove yang luas dan saat ini trend permintaan serta eksploitasinya cenderung terjadi peningkatan.

Hutan mangrove merupakan habitat utama kepiting untuk tumbuh dan berkembang (nursery ground) dikarenakan terdapat organisme kecil yang menjadi makanan dari kepiting bakau. Habitat alami kepiting bakau ialah di daerah perairan payau yang dasarnya berlumpur dan berada di sepanjang garis pantai yang banyak ditumbuhi pohon bakau (Murniati et al. 2016).

Fauna kepiting juga membantu dalam penyebaran seedling dengan cara menarik propagul kedalam lubang tempat persembunyiannya ataupun pada tempat yang berair. Aktifitas kepiting ini dampaknya sangat baik dalam kaitannya dengan distribusi dan kontribusi pertumbuhan dari seedling mangrove dari jenis Rhizophora sp, Bruguiera sp. dan Ceriops sp, terutama pada daerah yang sudah atau mulai terjadi konversi hutan mangrove (Pramudji, 2001). Penduduk dan pemanfaatan yang semakin bertambah, maka ekosistem hutan mangrove yang ada di Desa Lamanggo dan Desa Tope mengalami degradasi kualitas lingkungan dan luasan. Sehingga dalam konteks pemanfaatan maka aspek pengelolaan kawasan diketahui belum didukung dengan ketersediaan informasi ilmiah secara memadai. Untuk mengetahui struktur komunitas mangrove di Desa Lamanggo dan Desa Tope, untuk mengetahui kelimpahan kepiting bakau di hutan mangrove, dan untuk mengetahui hubungan antara kerapatan mangrove dengan kepadatan kepiting di Desa Lamanggo dan Desa Tope.

\section{METODE PENELITIAN}

\section{Lokasi Penelitian}

Penelitian dilaksanakan di Desa Lamanggo dan Desa Tope, Kecamatan Biaro, Kabupaten Kepulauan Siau, Tagulandang, Biaro (Gambar 1). Penelitian dilakukan di lima lokasi dengan titik kordinat yaitu : $2^{\circ} 5$ '56,4" LU-2 $2^{\circ}$ ' 54" LU dan $125^{\circ} 20^{\prime}$ 52,8" BT - $125^{\circ} 21^{\prime} 36^{\prime \prime}$ BT.

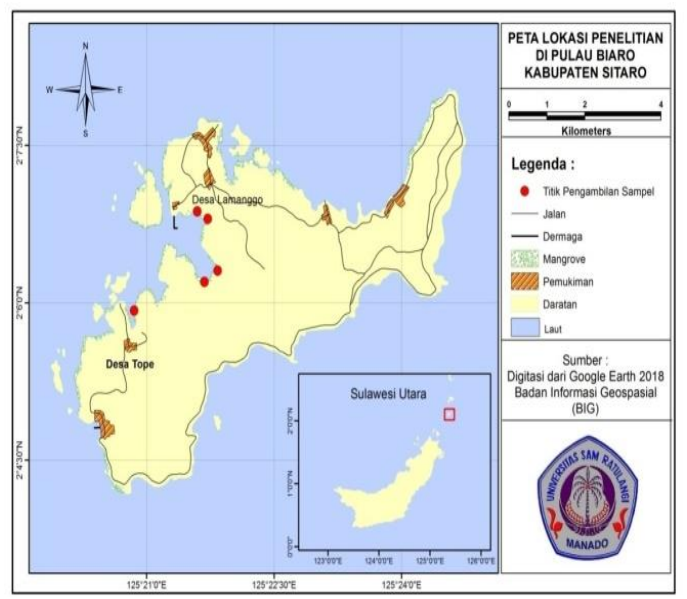

Gambar 1. Peta lokasi penelitian 


\section{Teknik Analisis Data}

Metode yang digunakan dalam penelitian ini yaitu metode line transek kuadran yang ditarik sepanjang 100 meter pada setiap titik lokasi, kemudian pada setiap transek diletakan/ditempatkan kuadran berukuran $10 \times 10 \mathrm{~m}$. Kemudian, pada setiap jenis tumbuhan mangrove dideterminasi dengan cara menyusuri setiap area yang sudah di blok kemudian diidentifikasi dan dihitung jumlah individu setiap jenis tumbuhan mangrove baik semai, tegakan dan pohon (Panduan pengenalan mangrove di Indonesia, Noor et al. 2006). Kemudian untuk pengambilan dan identifaksi (Panduan identifikasi spesies untuk tujuan perikanan, Carpenter and Angelis, 2014, Keenan and Blackshaw, 1999) sampel kepiting dilakukan dengan dua cara yaitu mengambi/memancing kepiting yang berada dalam lubang dengan menggunakan alat gancu, dan alat tangkap bubu ditempatkan disekitar tumbuhan mangrove dan diambil pada saat pasang naik.

\section{Analisis Data}

\section{Analisis Kondisi Ekosistem Mangrove}

Untuk mengetahui kondisi mangrove dilakukan perhitungan Kerapatan Jenis, frekuensi jenis, Indeks Nilai Penting dan keanekaragaman sebagaimana dapat dilihat dibawah ini (Bengen, 2000).

1. Kerapatan jenis (Di) (Bengen, 2000).

$$
\mathrm{Di}=\frac{\text { jumlahtotalindividuspesies }}{\text { luaspetakpengamatan }}
$$

2. Kerapatan relative (RDi) (Bengen, 2000).

$$
\mathrm{RDi}=\frac{\text { kerapatansuatujenis }}{\text { kerapatanseluruhjenis }} \times 100
$$

3. Frekuensi jenis (Fi) (Bengen, 2000).

$$
\mathrm{Fi}=\frac{\text { jumlah petak ditemukannya suatu jenis }}{\text { jumlah seluruh plotpengamatan }} \times 100
$$

4. Frekuensi relative (RFi) (Bengen, 2000).

$$
\mathrm{RFi}=\frac{\text { frekuensi suatu jenis }}{\text { frekuensi seluruh jenis }} \times 100
$$

5. Penutupan jenis (Ci) (Bengen 2000).

$\mathrm{Ci}=\frac{\text { jumlah basal area DBH jenis } \mathrm{i}}{\text { luas total area pengambilan contoh (plot) }} \times 100$

6. Penutupan relative (RCi) (Bengen 2000).

$\mathrm{RCi}=\frac{\text { luas penutupan jenis ke } \mathrm{i}}{\text { total luas area penutupan seluruh jenis }} \times 100$

7. Dari hasil perhitungan rumus diatas, kemudian dihitung indeks nilai penting (INP) dengan menggunakan rumus Bengen (2000).

$\mathrm{NNP}=\mathrm{RDi}+\mathrm{RFi}+\mathrm{RCi}$

8. Keanekaragaman (Odum,1971)

$$
\mathrm{H}^{\prime}=-\sum_{i=1}^{s} \frac{n i}{N} \operatorname{In} \frac{n \mathrm{i}}{N}
$$

\section{Analisis Kelimpahan Kepiting Bakau}

Kelimpahan kepiting bakau dapat dihitung dengan menggunakan rumus (Brower et al. 1990).

$$
K=\frac{n i}{A}
$$

Keterangan:

$$
\begin{aligned}
& \mathrm{K}=\text { Kelimpahan Jenis } \\
& \mathrm{ni}=\text { Jumlah Individu suatu jenis } \\
& \mathrm{A}=\text { Luas Area }
\end{aligned}
$$

Kelimpahan relatif kepiting bakau adalah perbandingan antara jumlah individu suatu spesies dengan total keseluruhan sebagai berikut.

Keterangan :

$$
K R=\frac{n i}{N} \times 100
$$

$\mathrm{KR}=$ Kelimpahan relatif

$\mathrm{ni}=$ Jumlah individu jenis $\mathrm{ke}-\mathrm{i}$

$\mathrm{N}=$ Jumlah total seluruh individu 


\section{Hubungan antara kerapatan mangrove dan kepadatan kepiting}

Untuk meihat hubungan antara dua variabel ( $X$ dan $Y$ ) yang berbeda, dilakukan pengujian model regresi sederhana. Dari data kerapatan mangrove dan kepadatan kepiting bakau, dengan rumus :

$$
Y=a+b X
$$

Dimana :

$$
\begin{aligned}
& \text { Y= Variabel terikat } \\
& \text { (KelimpahanKepiting Bakau) } \\
& a=\text { Konstanta } \\
& b=\text { Koefisien regresi } \\
& X=\text { Variabel bebas (Kerapatan } \\
& \text { Mangrove) }
\end{aligned}
$$

Keeratan hubungan antara kerapatan mangrove dengan kepadatan kepiting bakau dapat dilihat dari besarnya koefisien korelasi ( $r$ ) dan koefisien determinasi $\left(R^{2}\right)$. Nilai koefisien korelasi berkisar -1 sampai +1 , tanda negativ (-) menyatakan korelasi negative dan tanda positif (+) menyatakan korelasi positif. Nilai koefisien determinasi berkisar antara 0 sampai 1. Koefisien determinasi menggambarkan besarnya variasi indeks tetap (Y) dapat diterangkan oleh indeks bebas $(X)$. Sedangkan koefisien korelasi menggambarkan besarnya hubungan antara indeks bebas dengan indeks tetap.

\section{HASIL DAN PEMBAHASAN}

\section{Keanekaragaman Jenis Mangrove}

Hasil penelitian yang dilakukan di Desa Lamanggo dan Desa Tope ditemukan 6 jenis mangrove yang terdiri dari Avicennia officinalis, Bruguiera gymnorrhiza, Ceriops tagal, Rhizophora apiculata, Rhizophora mucronata, Sonneratia alba. Di Desa Tope ditemukan 4 jenis mangrove yaitu Bruguiera gymnorrhiza Rhizophora apiculata, Rhizophora mucronata, dan Sonneratia alba. Sedangkan di Desa Lamanggo ditemukan 6 jenis yaitu, Avicennia officinalis, Bruguiera gymnorrhiza, Ceriops tagal, Rhizophora apiculata, Rhizophora mucronata, Sonneratia alba. Dari hasil identifikasi terhadap mangrove yang tumbuh pada titik 1 sampai dengan titik 5, pada line transek yang ditarik sepanjang $100 \mathrm{~m}$ dalam 1 titik 10 plot yang masingmasing berukuran $10 \times 10 \mathrm{~m}$ maka jumlah seluruh individu dari jenis mangrove dapat di lihat pada (Tabel 1).

Tabel 1. Jumlah seluruh jenis mangrove yang terdapat pada titik 1 sampai dengan titik 5.

\begin{tabular}{llc}
\hline Titik & \multicolumn{1}{c}{ Jenis } & Jumlah pohon \\
\hline 1. & B. gymnorrhiza & 30 \\
& R. apiculata & 126 \\
& R. mucronata & 81 \\
& S. alba & 3 \\
\hline 2. & B. gymnorrhiza & 53 \\
& R. apiculata & 116 \\
& R. mucronata & 58 \\
& S. alba & 10 \\
\hline 3. & B. gymnorrhiza & 29 \\
& R. apiculata & 144 \\
& R. mucronata & 77 \\
& S. alba & 14 \\
\hline 4. & A. officinalis & 2 \\
& B. gymnorrhiza & 43 \\
& C. tagal & 9 \\
& R. apiculata & 157 \\
& R. mucronata & 62 \\
& S. alba & 11 \\
\hline 5. & A. officinali & 8 \\
& B. gymnorrhiza & 61 \\
& C. tagal & 13 \\
& R. apiculata & 163 \\
& R. mucronata & 78 \\
& S. alba & 9 \\
\hline & &
\end{tabular}

\section{Kerapatan Jenis dan Kerapatan Relatif}

Nilai kerapatan jenis tertinggi pada fase pohon dari titik 1 sampai titik 5 , dimiliki oleh jenis $R$. apiculata yaitu titik 1 dengan nilai $\left(1.26 \mathrm{ind} / \mathrm{m}^{2}\right)$, titik $2\left(1.16 \mathrm{ind} / \mathrm{m}^{2}\right)$, titik 3 $\left(1.44 \mathrm{ind} / \mathrm{m}^{2}\right)$, titik $4\left(1.57 \mathrm{ind} / \mathrm{m}^{2}\right)$ dan titik 5 (1.63 ind $\left./ \mathrm{m}^{2}\right)$ dengan nilai kerapatan relatif rata-rata $52.1 \%$ (Tabel 2). Sedangkan nilai kerapatan terendah yaitu jenis $A$. officinalis (0.02) dengan nilai kerapatan relatif ratarata $(1.56 \%)$. 
Tabel 2. Nilai rata-rata (\%) jenis mangrove pada fase pohon dari titik 1 sampai dengan titik 5.

\begin{tabular}{lcccc}
\hline Jenis & $\mathrm{RDi}$ & $\mathrm{RFi}$ & $\mathrm{RCi}$ & $\mathrm{INP}$ \\
\hline B.a & 15.9 & 18.2 & 15.7 & 49.8 \\
R.a & 52.1 & 36.1 & 6.70 & 94.9 \\
R.m & 26.5 & 30.6 & 7.09 & 64.2 \\
S.a & 3.47 & 9.38 & 66.7 & 79.6 \\
A.o & 1.56 & 4.82 & 4.01 & 10.4 \\
C.t & 3.55 & 9.63 & 5.37 & 18.5 \\
\hline
\end{tabular}

Tabel 3. Nilai rata-rata (\%) jenis mangrove pada fase tegakan dari titik 1 sampai dengan titik 5.

\begin{tabular}{lccl}
\hline Jenis & RDi & RFi & INP \\
\hline B.g & 16.84 & 16.77 & 33.61 \\
R.a & 47.17 & 38.69 & 85.86 \\
R.m & 34.66 & 33.83 & 68.5 \\
S.a & 4.27 & 10.8 & 15.07 \\
A.o & 1.64 & 3.45 & 5.09 \\
C.t & 3.28 & 6.9 & 10.18 \\
\hline
\end{tabular}

Pada fase tegakan, nilai kerapatan tertinggi sama dengan pada fase pohon yaitu dimiliki oleh jenis $R$. apiculata. Titik 1 (0.21), titik 2 (0.23), titik 3 jenis $R$. apiculata dan $R$. mucronata nilai kerapatannya sama (0.18), titik 4 (0.23) dan titik 5 (0.25) dengan nilai kerapatan relatifrata-rata jenis $R$. apiculata47.17\% (Tabel 3).

Untuk fase anakan nilai tertinggi pada titik 1 yaitu jenis $R$. apiculata dengan nilai kerapatan yaitu (0.22), kemudian di titik 2 jenis $B$. gymnorrhiza dan $R$. mucronata nilai kerapatannya sama $(0.08)$, titik 3 dimiliki jenis $R$. mucronata (0.14), titik 4 nilai kerapatan tertinggi oleh jenis $R$. apiculata (0.14), dan titik 5 dimiliki oleh jenis $R$. mucronata yaitu 0.08. Dengan nilai kerapatan relatif rata-rata didominasi oleh jenis $R$. apiculata $39.05 \%$ (Tabel 4 ).
Tabel 4. Nilai rata-rata (\%) jenis mangrove pada fase anakan dari titik 1 sampai dengan titik 5.

\begin{tabular}{lccc}
\hline Jenis & $\mathrm{RDi}$ & $\mathrm{RFi}$ & $\mathrm{INP}$ \\
\hline B.g & 20.16 & 21.03 & 41.19 \\
R.a & 39.05 & 31.81 & 70.86 \\
R.m & 32.34 & 37.82 & 70.16 \\
S.a & 5.58 & 6.05 & 11.63 \\
A.o & 7.89 & 9.42 & 17.31 \\
C.t & 3.13 & 4.55 & 7.67 \\
\hline
\end{tabular}

\section{Frekuensi Jenis dan Frekuensi Relatif}

Pada titik 1, jenis mangrove $R$. apiculata dan $R$. mucronata memiliki nilai frekuensi jenis tertinggi yang sama yaitu 100. Pada titik 2 sampai dengan titik $5 R$. apiculata memiliki nilai frekuensi jenis yaitu 100 dengan nilai frekuensi relatif rata-rata $36.01 \%$ (Tabel 2). Selanjutnya pada fase tegakan nilai frekuensi relatif rata-rata tertinggi yaitu jenis $R$. apiculata dengan nilai $36.69 \%$ (Tabel 3).

Kemudian fase anakan dengan nilai frekuensi jenis pada titik 1 yaitu dimiliki oleh jenis $R$. apiculata (90), titik 2 jenis $R$. mucronata nilai frekuensi jenis (80), titik 3 jenis $R$. apiculata dan $R$. mucronata memiliki nilai frekuensi jenis yang sama yaitu (80), titik 4 jenis $R$. apiculata memiliki nilai frekuensi yaitu (90), titik $5 R$. mucronata nilai frekuensinya yaitu (50). Nilai frekuensi relatif rata-rata didominasi oleh jenis $R$. mucronata dengan nilai $37.82 \%$ (Tabel 4).

\section{Penutupan Jenis dan Penutupan Relatif}

Penutupan jenis tertinggi pada fase pohon di titik 1 yaitu jenis $S$. alba dengan nilai $\left(211.66 \mathrm{ind} / \mathrm{m}^{2}\right)$, titik 2 jenis $B$. gymnorrhiza penutupan jenis tertinggi yaitu $\left(207.87 \mathrm{~m}^{2}\right)$, titik 3,4 dan 5 penutupan jenis tertinggi yaitu jenis $S$. alba, titik 3 (216.17 $\left.\mathrm{m}^{2}\right)$, titik 4 penutupan jenis $\left(216.30 \mathrm{~m}^{2}\right)$, titik 5 penutupan jenis $\left(196.30 \mathrm{~m}^{2}\right)$. Nilai penutupan relatif rata-rata didominasi oleh jenis $S$. alba dengan nilai $66.7 \%$ (Tabel 2).

Sedangkan jenis yang memiliki nilai penutupan jenis terendah yaitu $A$. officinalis, pada titik 4 dengan nilai $\left(10.28 \mathrm{~m}^{2}\right)$, dan di 
titik 5 (13.68 $\left.\mathrm{m}^{2}\right)$ dengan nilai penutupan relatif rata-rata $4.01 \%$ (Tabel 2 ). Karna hanya ditemukan pada titik 4 dan titik 5 . Faktor penting yang mempengaruhi nilai penutupan jenis adalah lingkaran batang pohon dan basal area dalam suatu lokasi pengambilan data. Dapat dilihat pada, penutupan jenis nilai yang lebih tinggi ditunjukan oleh jenis $S$. alba, ini disebabkan karena lingkaran batang pohon dari jenis $S$. alba lebih besar dari pada jenis-jenis mangrove yang ada pada titik pengamatan.

\section{Indeks Nilai Penting}

Bengen (2000) mengemukakan, Indeks Nilai Penting digunakan untuk melihat pertumbuhan mangrove dalam suatu komunitas dan dari analisis kondisi vegetasi dalam komunitas mangrove. Indeks Nilai Penting (INP) adalah penjumlahan nilai relatif (RDi), Frekuensi relatif $(\mathrm{RFi})$, dan Penutupan relatif $(\mathrm{RCi})$. Indeks Nilai Penting (INP) merefleksikan keberadaan peran (dominasi) dan struktur vegetasi mangrove disuatu lokasi. Berdasarkan hasil perhitungan INP, indeks nilai penting tertinggi terdapat pada fase pohon di titik 1 untuk jenis $R$. apiculata sebesar 100.59\% (skala 0-300), (Bengen 2000), titik 2 yaitu jenis B. gymnorrhiza (94.79\%). pada titik 3,4 dan 5 yaitu didominasi oleh jenis $R$. apiculata dengan INP, titik 3 (99.52\%), titik 4 (97.78\%), dan titik $5(87.27 \%)$. dan terendah ialah jenis $A$. officinalis terdapat pada titik 4 yaitu (7.59). Indeks nilai penting rata-rata tertinggi didominasi oleh jenis $R$. apiculata yaitu, 94.9\% (Tabel 2).

\section{Keanekaragaman}

Pada (Tabel 5) dapat dilihat keanekaragaman dengan nilai tertinggi pada titik 1 yaitu $H^{\prime}(0.37)$ dimilki oleh jenis B. gymnorrhiza. Sedangkan nilai terndah yaitu dimiliki oleh jenis $A$. officinalis (0.03), ini sebabkan oleh beberapa faktor fisikakimia.
Tabel 5. Keanekaragaman jenis mangrove di titik 1,2,3,4 dan 5

\begin{tabular}{|c|c|c|c|c|c|}
\hline & jenis & $\mathrm{Ni}$ & In ni & $\mathrm{Ni} \ln \mathrm{ni}$ & $\mathrm{H}^{\prime}$ \\
\hline \multirow[t]{4}{*}{1} & B. $g$ & 0.34 & -1.09 & -0.37 & 0.37 \\
\hline & R. $a$ & 0.53 & -0.64 & -0.34 & 0.34 \\
\hline & R. $m$ & 0.13 & -2.08 & -0.26 & 0.26 \\
\hline & S. a & 0.01 & -4.38 & -0.05 & 0.05 \\
\hline \multirow[t]{4}{*}{2} & B. $g$ & 0.22 & -1.50 & -0.33 & 0.33 \\
\hline & R. $a$ & 0.49 & -0.71 & -0.35 & 0.35 \\
\hline & R. $m$ & 0.24 & -1.41 & -0.34 & 0.34 \\
\hline & S. a & 0.04 & -3.17 & -0.13 & 0.13 \\
\hline \multirow[t]{4}{*}{3} & B. $g$ & 0.11 & -2.21 & -0.24 & 0.24 \\
\hline & R. a & 0.55 & -0.61 & -0.33 & 0.33 \\
\hline & R. $m$ & 0.29 & -1.23 & -0.36 & 0.36 \\
\hline & S. a & 0.05 & -2.94 & -0.15 & 0.16 \\
\hline \multirow[t]{6}{*}{4} & A. 0 & 0.01 & -4.96 & -0.03 & 0.03 \\
\hline & B. $g$ & 0.15 & -1.89 & -0.29 & 0.29 \\
\hline & C.t & 0.03 & -3.45 & -0.11 & 0.11 \\
\hline & R. $a$ & 0.55 & -0.60 & -0.33 & 0.33 \\
\hline & R. $m$ & 0.22 & -1.53 & -0.33 & 0.33 \\
\hline & S. $a$ & 0.04 & -3.25 & -0.13 & 0.13 \\
\hline \multirow[t]{6}{*}{5} & A. 0 & 0.02 & -3.73 & -0.09 & 0.09 \\
\hline & B. $g$ & 0.18 & -1.70 & -0.31 & 0.31 \\
\hline & C. $t$ & 0.04 & -3.24 & -0.13 & 0.13 \\
\hline & R. $a$ & 0.49 & -0.72 & -0.35 & 0.35 \\
\hline & R. $m$ & 0.23 & -1.44 & -0.34 & 0.34 \\
\hline & S. a & 0.03 & -3.61 & -0.09 & 0.10 \\
\hline
\end{tabular}

\section{Kelimpahan Kepiting}

Tabel 6. Kelimpahan jenis kepiting pada titik pengamatan.

\begin{tabular}{|c|c|c|c|}
\hline Titik & Jenis & $\mathrm{K}$ & $\mathrm{KR}(\%)$ \\
\hline \multirow[t]{3}{*}{1} & Scylla serata & 0.42 & 22 \\
\hline & Scylla & 0.01 & 1 \\
\hline & paramamosain & & \\
\hline 2 & Scylla serata & 0.43 & 23 \\
\hline \multirow[t]{3}{*}{3} & $\begin{array}{l}\text { Scylla } \\
\text { tranquebarica }\end{array}$ & 0.01 & 1 \\
\hline & Scylla serata & 0.31 & 16 \\
\hline & $\begin{array}{l}\text { Portunus } \\
\text { pelagicus }\end{array}$ & 0.01 & 1 \\
\hline \multirow[t]{2}{*}{4} & Scylla serata & 0.35 & 19 \\
\hline & $\begin{array}{l}\text { Portunus } \\
\text { pelagicus }\end{array}$ & 0.02 & 1 \\
\hline 5 & Scylla serata & 0.32 & 17 \\
\hline
\end{tabular}


Titik 1 didominasi oleh jenis $S$. serata dengan jumlah rata-rata sebanyak 42 individu sedangkan untuk jenis $S$. paramamosain hanya ditemukan 1 individu. Pada titik 2 jenis kepiting bakau yang ditemukan yaitu 43 individu jenis $S$. serata. Titik 3 ditemukan 3 jenis kepiting bakau yaitu, $S$. serrata, $S$. tranquebarica dan $P$. pelagicus. Pada titik 3 ini jenis $S$. serrata ditemukan 31 individu, $S$. tranquebarica 1 individu dan $P$. pelagicus 1 individu. Kemudian titik 4 ditemukan 35 individu untuk jenis $S$. serrata dan 2 individu jenis $P$. pelagicus. Selanjutnya pada titik 5 ditemukan hanya jenis $S$. serrata yaitu 32 individu (Tabel 6).

\section{Kelimpahan Relatif}

Kelimpahan relatif $S$. serrata yang tertinggi terdapat pada titik 2 yaitu 23\%,. Kisaran nilai kelimpahan relatif tergolong rendah. Hal ini dikarenakan kehidupan semua jenis kepiting bakau bergantung pada habitat mangrove, pada saat juvenile hingga remaja kepiting bakau akan menetap di hutan mangrove dan saat dewasa akan berpindah ke perairan laut untuk memijah. Kepiting bakau akan kembali lagi ke hutan mangrove pada siang hari mengikuti pergerakan pasang surut air laut.

Dari hasil pengamatan yang dilakukan, kerapatan mangrove tertinggi pada titik 5 yaitu jenis $R$. apiculata untuk fase pohon $1.63 \mathrm{ind} / \mathrm{m}^{2}$, tegakan 0.24 ind $/ \mathrm{m}^{2}$ dititik lima oleh jenis $R$. apiculata dan anakan $0.22 \mathrm{ind} / \mathrm{m}^{2}$ dititik 1 oleh jenis $R$. apiculata.

\section{Hubungan Antara Kerapatan Mangrove dan Kepadatan Kepiting}

Gambar 2 menjelaskan, analisis korelasi sederhana kerapatan pohon mangrove terhadap kepadatan kepiting bakau menghasilkan koefisien korelasi sebesar $r=0,814$. Berdasarkan uji korelasi antara kerapatan pohon mangrove $(\mathrm{X})$ terhadap kepadatan kepiting $(\mathrm{Y})$

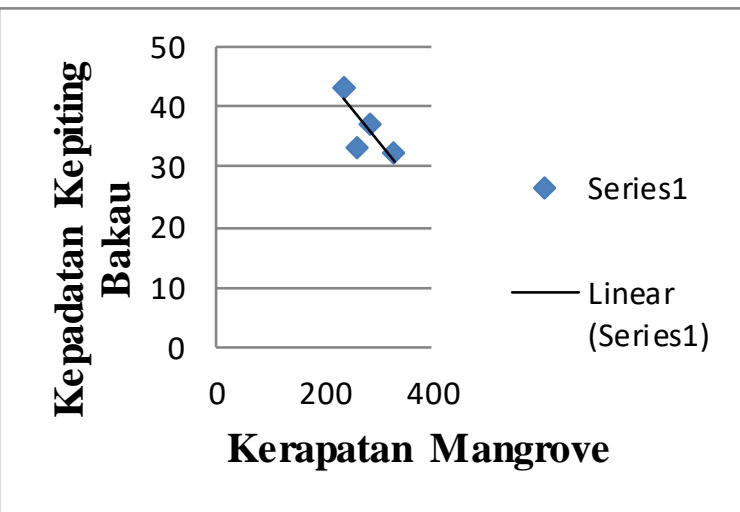

Gambar 2. Regresi Linier (Model observasi)

sebagaimana terlihat diperoleh $r$ sebesar $=$ 0,814 dengan $F_{\text {hitung sebesar } 1.94<\text { Ftabel }}$ 10.12. Hal ini berarti tidak terdapat hubungan yang signifikan antara kerapatan mangrove dengan kepadatan kepiting bakau. Selanjutnya untuk melihat besarnya kontribusi kerapatan mangrove terhadap kepadatan kepiting dicari melalui koefisien determinasi $R^{2}=0.66$ yang berarti variabel kerapatan pohon mangrove tidak memberikan kontribusi terhadap kepadatan kepiting. Karena jika setiap penambahan variabel $X$, maka variabel $Y$ akan berkurang sebesar $67.54937-0.110 X$.

Pengaruh antara kerapatan pohon mangrove dan kelimpahan kepiting bakau diperoleh persamaan regresi $\mathrm{Y}=389,3+$ $0,0348 x$ artinya setiap kenaikan kerapatan mangrove 1 satuan akan meningkatkan kelimpahan kepiting bakau sebesar 0,0348 atau kerapatan mangrove sebanyak 1000 satuan meningkatkan kelimpahan kepiting bakau sebesar 34,8 individu. Koefisien korelasi $(r)$ yang diperoleh adalah 0,4970 artinya hubungan antara kerapatan mangrove dengan kelimpahan kepiting bakau tergolong lemah yaitu sebesar 49,70\% ( Manalu et al. 2015).

\section{KESIMPULAN}

Dari hasil penelitian disimpulkan, enam jenis mangrove yang ditemukan di Desa Lamanggo dan Desa Tope dan yang paling banyak ditemukannya yaitu jenis $R$. apiculata (Rhizophoracea). Dari 5 titik 
penelitian, $R$. apiculata memiliki nilai kerapatan tertinggi $(1.26,1.16,1.44,1.57$, dan 1.63) dengan nilai kerapatan relatif (52.5\%, 48.95\%, 54.55\%, 55.28\% dan $49.10 \%$ ). Sedangkan nilai frekuensi jenis pada titik $1 R$. apiculata dan $R$. mucronata memiliki nilai yang sama yaitu 100 . Selanjutnya pada titik 2-5 $R$. apiculata memiliki frekuensi jenis (100) dengan nilai frekuensi relatif $(41.67 \%, 35.71 \%, 37.04 \%$, $35.71 \%$ dan $30.30 \%$ ). Sedangkan untuk nilai dominasi pada 5 titik penelitian yaitu, jenis $S$. alba memiliki nilai dominasi yang paling tinggi (216.30) pada titik 4 dengan dominasi relatif tertinggi terdapat pada titik 3 yaitu (77.03\%), karena kepadatan $S$. alba lebih tinngi. Keanekaragaman di Desa Lamanggo dan Tope didapatkan nilai yang rendah menunjukan kondisi ekologi yang tidak stabil.

Hasil penelitian yang dilakukan di Desa Lamanggo dan Tope ditemukan 4 jenis kepiting yang terdiri dari $S$. serrata, $S$. paramamosain, $S$. tranquebarica dan $P$. pelagicus. Dari titik 1 sampai dengan titik 5 didominasi oleh spesies $S$. serata.

Karena $F_{\text {Tabel }}$ lebih besar dari

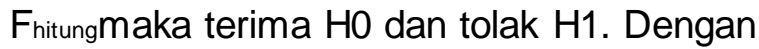
demikian tidak terdapat pengaruh yang signifikan antara hubungan kerapatan mangrove dan kepadatan kepiting, karena variabel $X$ tidak dapat berpengaruh terhadap variabel $Y$. Jika setiap penambahan variabel $\mathrm{X}$, maka variabel $\mathrm{Y}$ akan berkurang sebesar 67.54937-0.110 X.

\section{DAFTAR PUSTAKA}

Bengen, D G. 2000. Pedoman Teknis Pengenalan Dan Pengelolaan Ekosistem Mangrove. PKSPL-IPB. Bogor.

Brower, J.Z., Yerrold, C., Von Ende, 1990. Field and Laboratory Methods for Genera Zoologi : Third Edition. W.M.C. Brown Publiser United States of America.

Carpenter, K E., Angelis N. D. 2014. The living marine resources of the Eastern central atlantic. Volume 1:
Introduction, crustaceans, chitons, and cephalopods. E-ISBN 978-92-5107847-1 (PDF).

Keenan, C.P., Blackshaw, A. 1999. Mud Crab Aquaculture and Biology: Proceedings of an International Scientific Forum held in Danwin, Australia, 21-24 April 1997. ACIAR Proceedings No. 78. Australian.

Kusen, J.D. Lumingas. L.J.L. Rondo. M. 2016. Ekologi Laut Tropis. FPIK UNSRAT. ISBN 978-602-0847-03-0.

La Sara. 2010. Study on the Size Structure and Population Parameters of Mud Crab Scylla serrata in Lawele Bay, Southeast Sulawesi, Indonesia. Journal of Coastal Development ISSN : 1410-5217 Volume 13, Number 2, February, 2010 : 133-147 Accredited : 83/Dikti/Kep/2009.

Manalu, T.N., Yunasfi, Rusdi L. 2015. Hubungan Kerapatan Mangrove Terhadap Kelimpahan Kepiting Bakau (Scylla spp.) Di Desa Tanjung Rejo Kecamatan Percut Seituan Kabupaten Deli Serdang Provinsi Sumatera Utara. https://jurnal.usu.ac.id/index.php/aqu acoastmarine/article/viewFile/13347/ 608

Martuti N.K.T. 2013. Keanekaragaman Mangrove di Wilayah Tapak, Tugurejo, Semarang. Jurnal MIPA 36 (2):123-130.

Murniati, D C. Wawing W., Adang S. 2016. Petunjuk Teknis Pelepasliaran Kepiting Bakau (Scylla spp). Pusat Karantina dan Keamanan Hayati Ikan Badan Karantina Ikan, Pengendalian Mutu dan Keamanan Hasil Perikanan Kementerian Kelautan dan Perikanan Kerjasama Pusat Penelitian BIOLOGI-LIPI.

Noor, Y R,. Khazali M., Suryadiputra I.N.N. 2006. Panduan Pengenalan Mangrove di Indonesia. PHKAWWIIP, Bogor. 
Odum, E.P. 1971. Dasar-Dasar Ekologi. Edisi ketiga Gadjah Mada University Press. Yogyakarta. 697 hal.

Pramudji, 2001. Ekosistem Hutan Mangrove dan Peranannya Sebagai Habitat Berbagai Fauna Aqutik. Oseana, Volume XXVI, Nomor 4:13 - 23. ISSN 0216-1877.

Unthari, D.T., Anna, I.P., Andi A. 2018. Hubungan Kerapatan Mangrove Terhadap Kelimpahan Kepiting Bakau (Scylla sp) dengan Penggunaan Bubu Lipat Sebagai Alat Tangkap di Sungai Bungin Kabupaten Banyuasin, Provinsi Sumatera Selatan. MASPARI JOURNAL Januari 2018, 10(1):41. 